\title{
Dental Paleopathologies in the Sanders Site (41LR2) Population from Lamar County, Texas
}

Diane E. Wilson

Unknown

Follow this and additional works at: https://scholarworks.sfasu.edu/ita

Part of the American Material Culture Commons, Archaeological Anthropology Commons, Environmental Studies Commons, Other American Studies Commons, Other Arts and Humanities Commons, Other History of Art, Architecture, and Archaeology Commons, and the United States History Commons

Tell us how this article helped you.

This Article is brought to you for free and open access by the Center for Regional Heritage Research at SFA ScholarWorks. It has been accepted for inclusion in Index of Texas Archaeology: Open Access Gray Literature from the Lone Star State by an authorized editor of SFA ScholarWorks. For more information, please contact cdsscholarworks@sfasu.edu. 
Dental Paleopathologies in the Sanders Site (41LR2) Population from Lamar County, Texas

\section{Creative Commons License}

(c) (1) (8)

This work is licensed under a Creative Commons Attribution-NonCommercial 4.0 International License 


\section{Dental Paleopathologies in the Sanders Site (41LR2) \\ Population from Lamar County, Texas}

Diane Wilson

\section{Introduction}

Dental health, like skeletal health, reflects the natural and social environment, as well as genetics. This paper focuses on the results of stress on the teeth once they have erupted; stresses include chemical, mechanical, and pathogenic forces. These forces are primarily the result of dietary factors. The specific aspects of dental health examined in this paper are cariogenesis, dental attrition, antemortem tooth loss, and abscessing. These dental paleopathologies primarily reflect diet and food processing strategies.

Throughout the Americas, dental disorders have increased with the adoption of maize agriculture. Reliance on maize provides a sticky, carbohydraterich dietary staple that is favorable to microbial attack. Maize cultivation has been correlated with an increase in caries and abscess frequency (e.g., Stodder and Martin 1992).

Poor dental health also may directly impact general physical health. Periodontal disease often results in gingival inflammation, abscessing, and tooth loss. Lesions in the mouth can be the port of entry for pathogens, such as staphylococci and streptococci, that may then travel to other parts of the body.

Dental attrition is not considered a disorder in this paper, but the natural result of a diet high in unprocessed vegetal materials and grit. Grit is introduced into the diet from a variety of means, but I will focus on the introduction of grit through stone grinding implements. Sand particles can also result in a considerable amount of attrition. Dental attrition can, however, lead to pathologies if the pulp cavity is 
exposed. In this case, the pulp cavity may serve as the focus of infection, resulting in abscessing and eventual tooth loss.

Dental health is thus largely dependent on dietary factors. The examination of dental health is useful in reconstructing nutritional behaviors. It will be seen in this examination of the teeth that the maize agriculturalists at the Sanders site were primarily affected by a high frequency of caries. Other factors examined (moderate dental enamel attrition, slight antemortem tooth loss, and slight abscessing) suggest that dietary behaviors were not as detrimental to the Sanders population as has been noted for other maize-dependent agricultural groups. If nutrition was related to status among Caddoan groups, this may be the result of the assumed high status of the individuals interred at the Sanders site, since all the individuals were interred in a mound context (see Krieger 1946).

\section{The Archaeological Setting}

The term Caddo has been applied to an archaeological culture in northeastern Texas, southwestern Arkansas, eastern Oklahoma, and northwestern Louisiana via the direct historical approach, and this term will be used as such in this paper. The archaeological manifestation known as Caddo is believed to have arisen in situ (see Story 1990) as a group of maize agriculturalists that occupied roughly the same area occupied by the Caddo in early historic times. The Sanders site is included in this archaeological culture.

The Sanders site has not yet been dated by absolute means; however, it was placed within the Gibson Aspect by Krieger (1946), and more recently in the Sanders phase of the Early to Middle Caddoan period by Story (1990) and Bruseth (1995). Current estimates are that the Caddoan occupation at the Sanders site may date between ca. A.D. 1100-1300 (see Bruseth 1995; Bruseth et al. 1995). 
The Sanders site (41LR2) is located in northeastern Texas on the western edge of the Caddoan area, approximately $1.6 \mathrm{~km}$ west of Direct, Texas, in the northwestern corner of Lamar County (Figure 1). The site consists of two mounds and a low ridge of habitation rnidden located on the edge of a river terrace on the eastem side of Bois d'Arc creek. Bois d'Arc creek is a tributary of the Red River, flowing some $5 \mathrm{~km}$ northeasterly from the Sanders site to its confluence with the Red River.

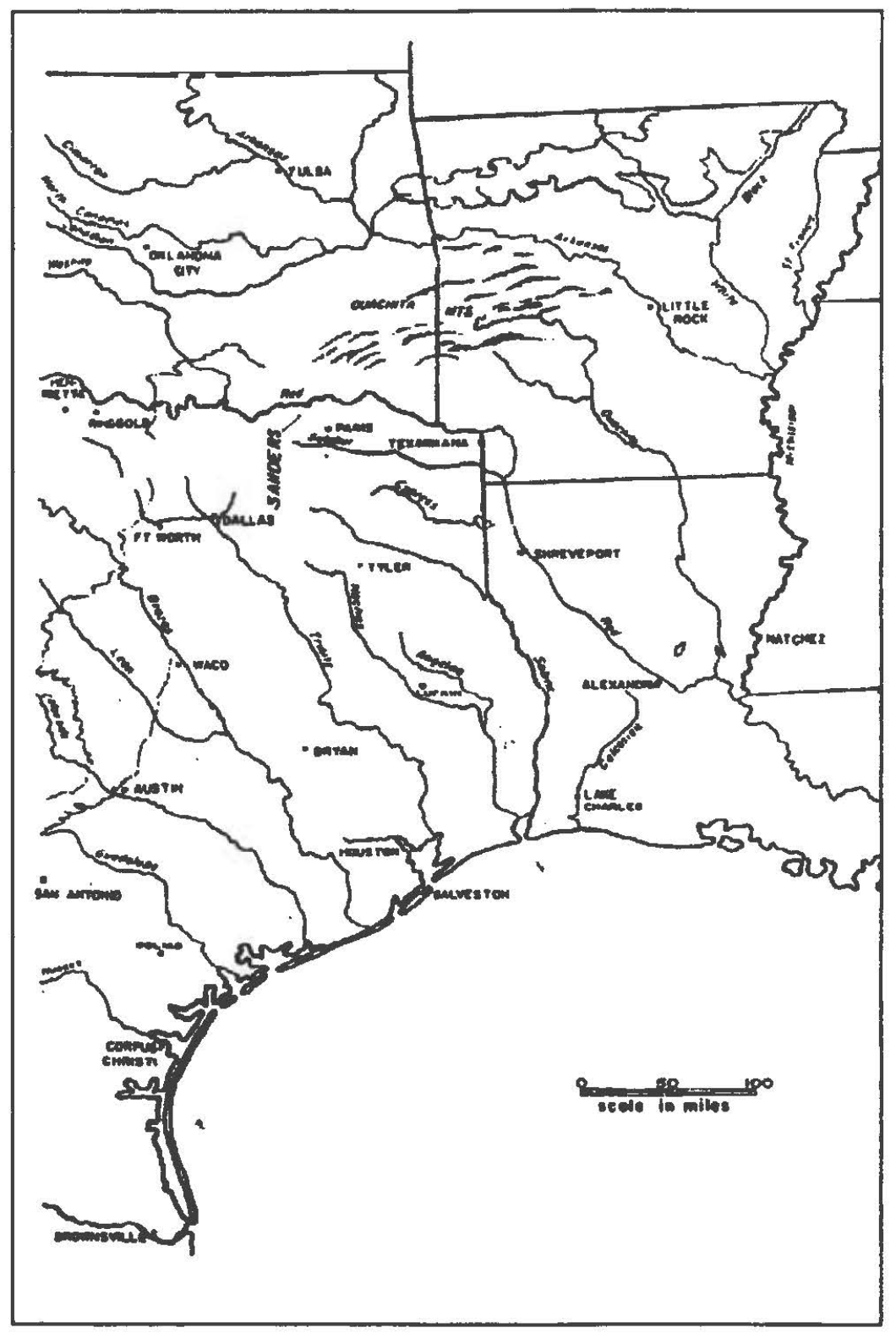

Figure 1. The Location of the Sanders Site in northeastern Texas. 
Excavation at the site took place in the summer of 1931 under the direction of A. T. Jackson and B. B. Gardener from the University of Texas. Jackson thoroughly excavated Mound 1, and trenched Mound 2 and the midden (Figure 2). The Sanders site is considered to have been the center of a large region of Caddoan interaction (cf. Newkumet and Meredith 1988:39). Artifacts recovered from the site indicates its nearly continuous use up to historic times, although the historic period occupation may have been by Wichita-speaking groups (see Bruseth et al. 1995). Nevertheless, while the artifacts differ by depth, the graves are relatively homogenous in form and burial offerings, suggesting that the burials represent a discrete period of use during the Sanders phase occupation of the site.

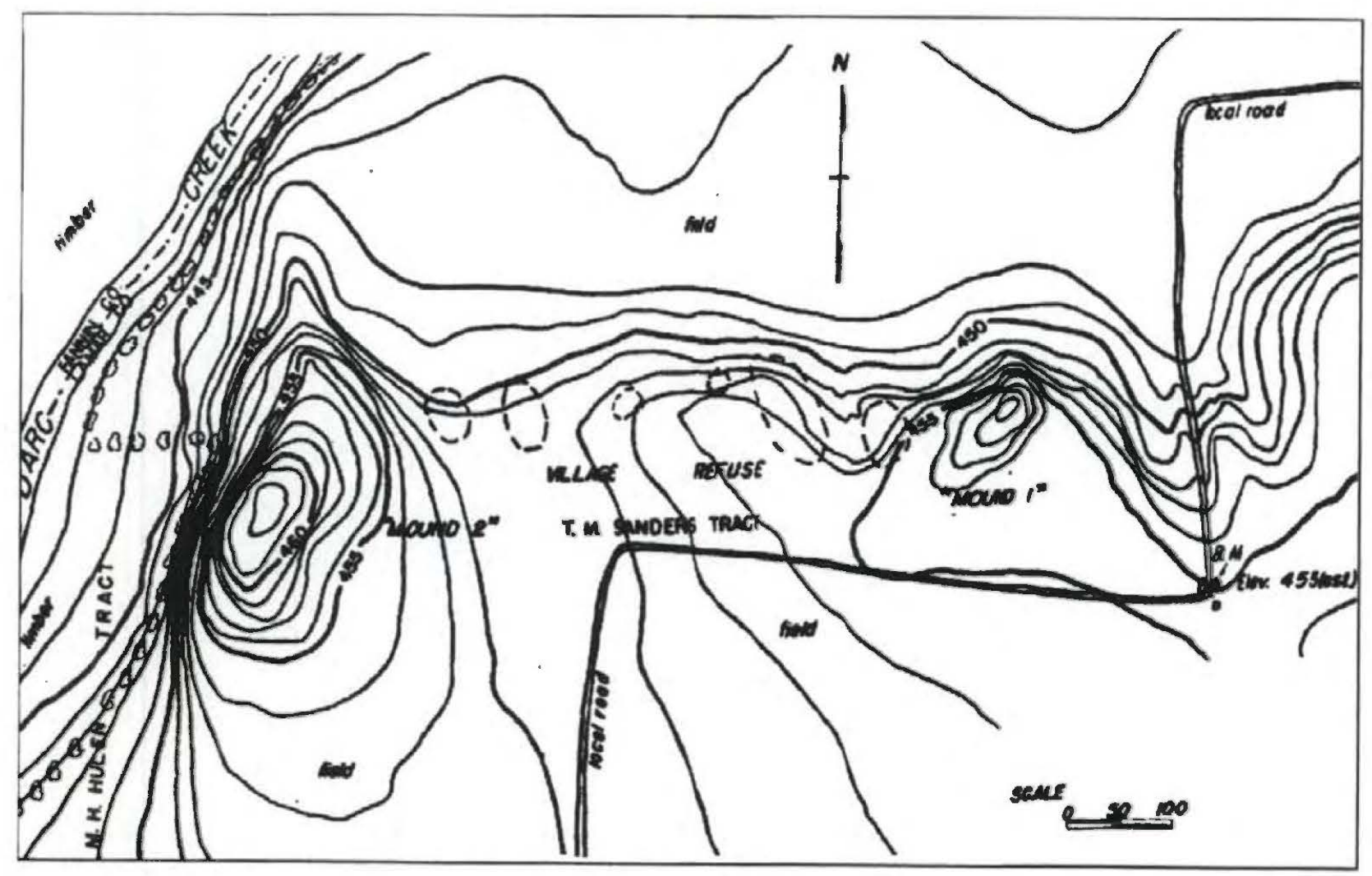

Figure 2. Map of the Sanders Site (from Krieger 1946:173).

Jackson recovered some 90 individuals from two locations in Mound 1. One group was placed in the top of the mound, while the other group was located 
on the eastern side of the mound (Figure 3). There were no apparent differences between the two groups in burial form or offerings. Both single and multiple interments were found in both groups, and all individuals were in the supine, extended position, or lying on their side. All had their heads oriented to the east except one individual whose head was oriented to the west. Nearly all individuals exhibit frontal and occipital deformation. Demography within the burial population falls within the range of a normal population curve: 33 adult females, 25 adult males, 18 adults of indeterminant sex, and 21 children.

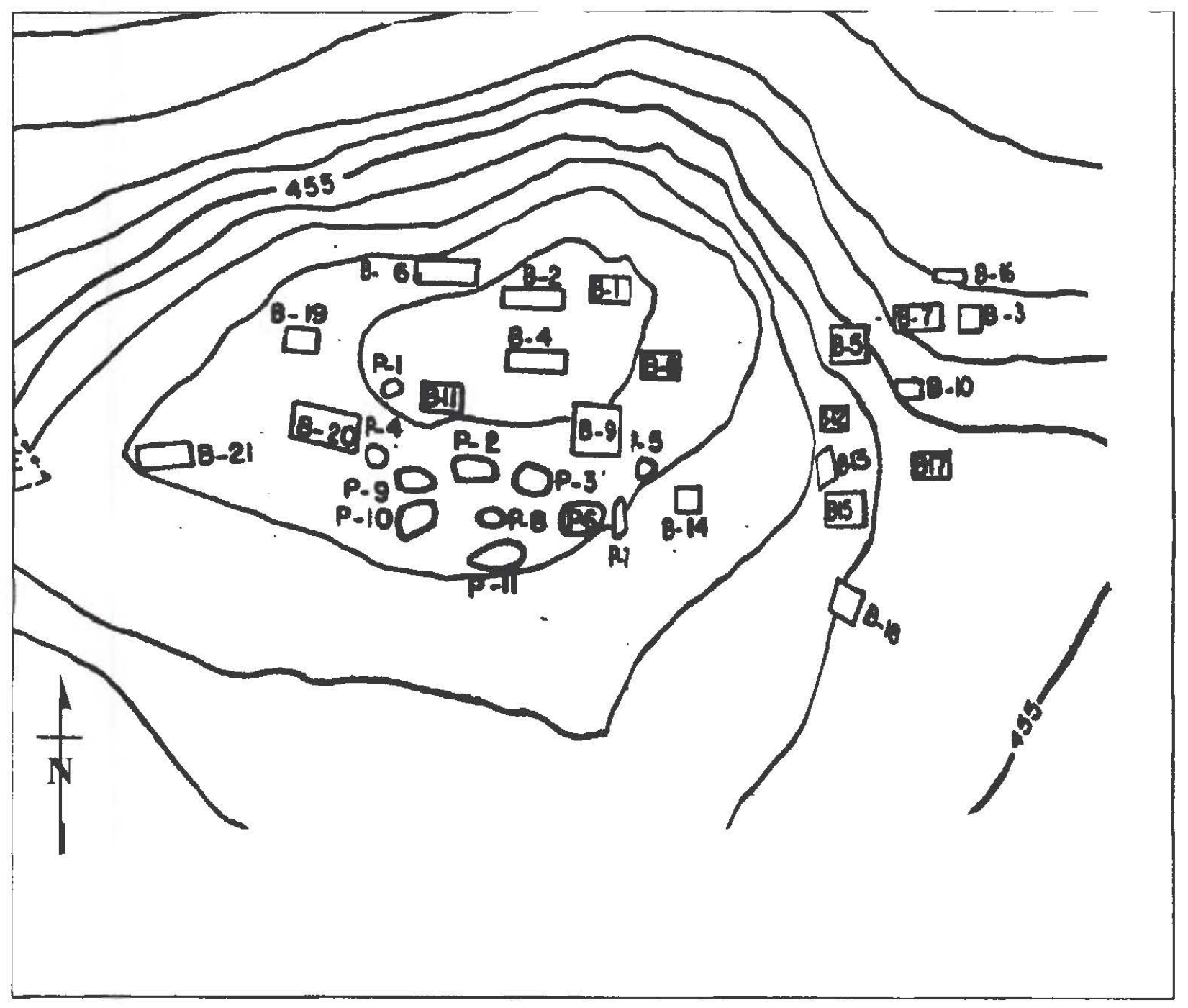

Figure 3. The Burial Locations in Mound 1 at Sanders (from Krieger 1946:176). 
Recently, the Sanders site and its population has fallen under controversy surrounding the ethnic and cultural origins of its inhabitants (Schambach 1993). It is my hope that by comparing the results presented here with other Caddoan populations, a first step towards identifying the ethnicity of the Sanders population will be achieved.

\section{Age of the Sample}

Before this investigation of the dentition from the Sanders site begins, it is important to familiarize the reader with the age and demographic composition of the studied assemblage. Only individuals with dental remains were considered for study. In all, this included eight children and 43 adults of the 90 reported recovered from the excavations (57 percent of the total assemblage). No infants were recovered from the burials, and the youngest age group represented was aged from 3 to 5 years.

The age range included in this sample was fairly large, with the oldest individual aged about 60 years. Age at death was estimated using a variety of techniques. Older adult age at death was estimated by: pubic symphysis (McKem and Stewart 1957; Stewart 1979); auricular surface (Lovejoy et al. 1985); and fourth right rib morphology (Iscan and Loth 1986) when available. Unfortunately, in most cases these particular skeletal remains were not preserved for analysis. In this case, ectocranial suture fusion was used for age estimation (Steele and Bramblett 1988; Meindl and Lovejoy 1985). For children and young adults, dental eruption (Ubelaker 1978), crown and root formation stages (Smith 1991), and long bone fusion were used to assess ages. Because ectocranial suture fusion was used in so many cases, when other age techniques were used to asses adult age, ectocranial age was also estimated; in most cases, the ages agreed to within a five year time span. Therefore, I feel that the age estimates are fairly accurate. 
The average age of death for the entire Sanders population studied here was approximately 29 years. Because this figure may be indicative of fertility as well as mortality, the average age of death for individulals 15 years and older was calculated to be 32.8 years. The average age of death for males exceeded female mean age of death slightly at 34.9 years and 30.2 years, respectively. This difference was not statistically significant in a Chi-square test at the 0.05 level. The sex of adults was determined by examining pelvic morphology, femoral and humeral head diameters (Stewart 1979), and facial and cranial morphology. Of the adult population for which sex could be determined, 21 were female and 18 were male. Thus, the sex ratio of the original burial population differed slightly from the sample, at 0.75 and 0.85 percent, respectively. Age representation of the sample also differs from the Sanders burial population as a whole (Dow 1987; Figure 4). These factors should be kept in mind when evaluating the conclusions reached in this paper.

Eight hundred fifty-two teeth were examined in all for this study. Fifty-one of 77 individuals curated at the Texas Archeological Research Laboratory were included here on the basis of possessing mandibles and maxillas from which observations on dentition were possible. No criteria to discriminate between poorly and fully represented individuals were employed; in other words, if an individual lacked a maxilla and had only half of the mandible the individual was included for analysis. Likewise, individuals who had lost most or all of their teeth prior to death were also included in this analysis of dental health because it was felt that this information was vital as this may represent an extreme case of dental paleopathology. Individuals from the Sanders site in this sample averaged 16.7 teeth per dentition, and ranged from one individual that had lost all of his teeth prior to death (\#361), to one individual that had all 32 teeth accounted for (\#407). 


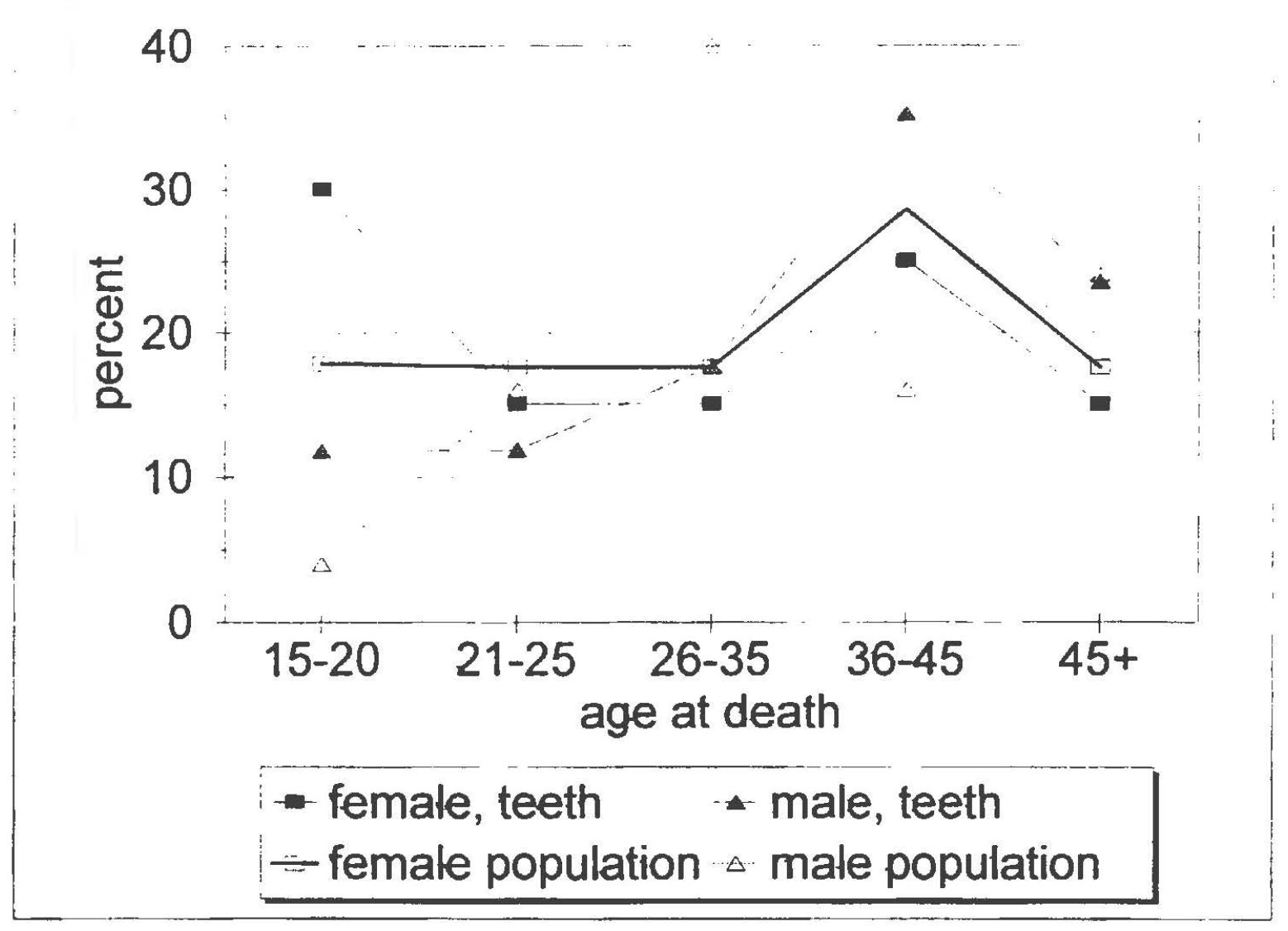

Figure 4. Age Representation of the Sanders adult population and representation of the Sanders adult population with dentitions.

\section{Results}

\section{Caries}

There are two basic components to consider in examining caries frequency. One is age and the second is diet. A sticky carbohydrate-rich diet high in sucrose should produce a relatively high rate of caries. Bacteria (Lactobacillus acidophilus and Streptococcus mutans) in the mouth convert sucrose in maize into 
an acid that destroys enamel and dentin (Molnar 1971; Larsen 1984; Powell 1985; Kestle 1988). Rose et al. (1984) suggested that the incidence of caries in the diet covaries with the amount of maize consurmed. Stable carbon isotope analysis should better elucidate this relationship, because as the Sanders case shows, the maize to caries relationship is not linear, which suggests that maize should not be the only dietary item rich in sucrose to be considered when examining dental health.

The Sanders population, like many other populations across the southern and eastern United States, practiced maize agnculture. Frequencies of caries fall within the maize agriculture range of 8-25 percent (Turner 1979; Cohen and Armelagos 1984; Powell 1985; Kestle 1988). Of the teeth examined, 19 percent were carious; in fact, 79 percent of the individuals examined had at least one dental caries.

Limited stable carbon isotope sampling from the site indicates a maize intensive diet with stable carbon isotope delta ${ }^{13} \mathrm{C}$ values ranging from $-10.0 \%$ o to $-12.9 \%$ o (Wilson and Cargill 1993). It was expected that the high concentration of maize in their diet would be reflected in a high occurrence of caries, and this in fact seerms to be the case.

Larsen et al. (1991) use a percentage of carious teeth greater than 7 percent to determine the prevalence of maize diets. Among other investigations of Caddoan sites, caries frequencies vary greatly. This may be a product of the kind of sampling of bioarchaeological populations that has taken place among sites in the Caddoan area more than actual frequencies. Powell (1985:327) found 25.3 percent of the teeth from her Caddoan sample carious and 90.6 percent of the individuals examined had caries. In a different Caddo sample, Powell and Rogers (1980) found 43.4 percent of the teeth examined to be carious, and again 90.6 percent of the individuals had caries. Other comparative data come from the 
Belcher Mound, Bentsen-Clark, and Sam Kaufman sites where the frequency of carious teeth were 10.7, 14.1, and 16.2 percent, respectively (Webb 1959; Buikstra and Fowler 1975; Butler 1969).

Others have used what is called a caries rate for comparison (Table 1). The caries rate is equal to the number of caries divided by the number of individuals in the population. Rose and Marks (1985) have used a caries rate of 2.0 to differentiate between a high and low carbohydrate diet. The caries rate from the Sanders site population is above the 2.0 mark at 3.3 caries per individual, indicating a high carbohydrate diet. This average fits within the range of caries for Middle-Late and Late Caddoan period sites in the Red River drainage (Burnett 1990:392,394).

Table 1. Caries Rates among Fourche Maline and Caddoan Sites (After Burnett 1990)

\begin{tabular}{llll}
\hline Site & Cultural Affiliation* & N & $\begin{array}{l}\text { Caries } \\
\text { Rate }\end{array}$ \\
& & & \\
\hline Old Martin Place & Terminal FM, Caddo I & 12 & 2.8 \\
Bowman & Terminal FM, Caddo I-Late & 12 & 2.5 \\
Tigert & Caddo & 1 & 2.0 \\
George C. Davis & Early Caddo & 14 & 1.2 \\
Mineral Springs & Early Caddo & 2 & 3.5 \\
41HS74 & Early-Middle Caddo & 8 & 0.3 \\
Roden & Middle Caddo & 14 & 2.7 \\
Sam Kaufman & Middle-Late Caddo & 23 & 3.1 \\
Roden & Late Caddo & 30 & 2.8 \\
Kaufman-Williams & Late Caddo & 75 & 3.5 \\
Mitchell & Late Caddo & 71 & 0.3 \\
Alex Justiss & Late Caddo & 1 & 1.0 \\
\hline F F Fourdo & & & \\
\hline
\end{tabular}

* FM=Fourche Maline

Note: Compare to the caries rate of 3.3 for the Sanders population

Females had higher frequencies of caries than did males. Thirty-nine individuals had caries, and of these 19 were female while 13 were male. Females averaged 4.4 caries per individual, while males averaged 2.5 . This difference was 
not statistically significant in a Chi-square test at the 0.05 significance level. In all, 18 percent of the 376 female teeth examined were carious, while 11.7 percent of the 308 male teeth were carious. This is contrary to the age distribution of the population, suggesting that caries were not strictly age progressive. This may be due to a difference in diet.

Although only one male and two females were sampled for stable isotope analysis, results suggested that males consumed more maize than females (Wilson and Cargill 1993). Caries rates contradict this notion, and it may be that simply more individuals need to be tested for stable carbon isotopes before conclusive relationships can be determined. Since this represents a Caddoan site, Caddoan females were described ethnohistorically as preparing food, so it is possible that a good deal of snacking was going on among females. However, stable isotopes suggest that females were not snacking on maize. Additionally, the ritual importance of maize agriculture, particularly among the males, is noted in the oral traditions of the Caddo (Newkumet and Meredith 1988:29), so it is questionable as to who would have consumed more maize.

It seems likely that maize is not the sole culprit, but persimmons and nuts instead may be responsible for a difference in diet between females and males. Persimmons and various species of nuts, including hickory and walnut, were noted ethnohistorically as a food sourrce among the Caddo (Swanton 1942), and these are $\mathrm{C}_{3}$ plants. It would therefore be possible that females consumed a greater quantity of this fruit (high in sucrose) than males, creating more caries in females.

Diet may not be the cause of higher caries rates among females. Among most archaeological and modern populations, caries rates appear to be higher among females than males (Kestle 1988; Larsen et al. 1991; Kelley et al. 1991; Walker 1986; Hillson 1986). Sanders is not the only population for which stable isotopic and trace element results suggest that diet is not the primary cause in 
dental caries (Kestle 1988; Hillson 1979; Larsen et al. 1991; Kelley et al. 1991). It is possible that there are physiological reasons for this difference, although anthropological and dental sources are inconclusive as to the specific cause (Walker 1986). Female teeth do erupt earlier than males, and therefore they are exposed to risk for a longer period of time than male dentition. It is presumable that this would result in a slightly greater frequency of lesions among females, like that seen at Sanders. It should be noted that there are some exceptions to the general pattern of female caries prevalence (Walker and Hewlett 1990).

Caries are also believed to be age progressive. In fact, this relationship could not be determined in the Sanders population (Figure 5). Others, including Hillson (1979), have not found a positive correlation between age and caries frequency. There is a slightly negative correlation of -0.14 for number of caries and age. When the number of teeth are considered as well, the correlation becomes positive, but is still very slight with a coefficient of $R=0.28$; when antemortem tooth loss is added to the equation, the correlation coefficient drops to 0.25 . This only explains 9 and 8 percent of the data, respectively, and is therefore not considered a valid relationship.

The Sanders population was divided into age categories of $6-17,18-30$, $31-45$, and $46+$ years of age. Caries decreased with increasing age for the entire Sanders population. This correlation was especially apparent for the males, and the Pearson's R coefficient revealed a -0.53 correlation. The females, on the other hand, had no clear relationship between age and number of caries, as indicated by a Pearson's R correlation coefficient of 0.00 . 


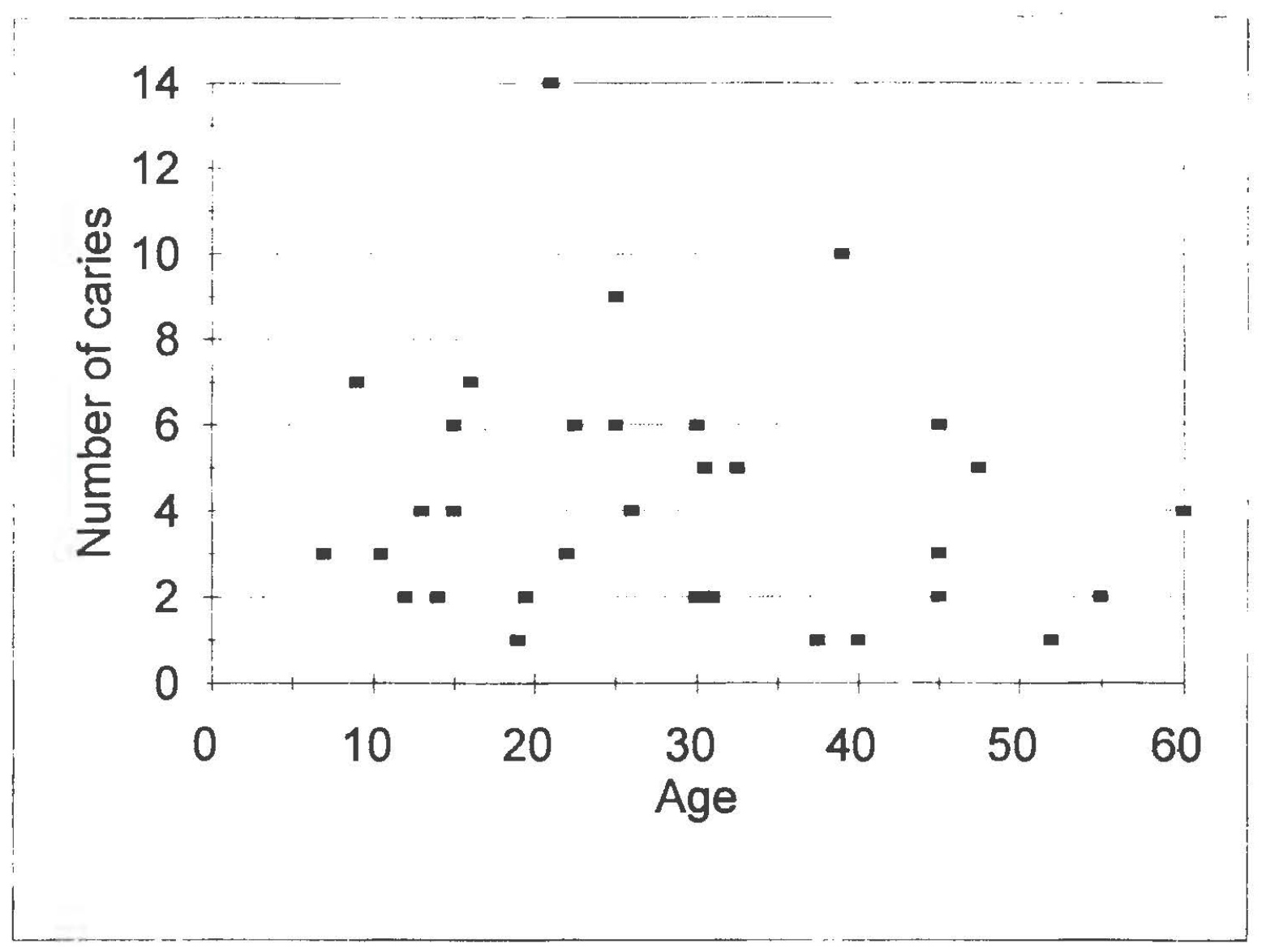

Figure 5. Age Distribution of Caries Frequency.

This relationship may be due to differential antemortem tooth loss which was considerably greater among males than females as well as age progressive. Males had a total of 74 antemortem teeth lost out of 382 observations, while females had a total of 43 antemortem teeth lost out of 419 observations. This difference was significant at the 0.05 significance level in a Chi-square test.

When antemorterm tooth loss is considered, females had a slight correlation with a coefficient of 0.10 . Males, on the other hand, yielded a Pearson's R of 0.67 , which approaches acceptability in archaeological data sets. In this situation, males caries rates may actually have been greater than female rates, as well as more severe, resulting in eventual loss of the affected teeth. 
When location of caries was analyzed, it was clear that the majority occurred on the crown of the tooth in pits and grooves (Table 2). Powell (1985) found this to be true among both the Fouche Maline sample and the Caddoan sample she analyzed. Burnett (1988) found this to also be the case among the Ouachita River and Standridge samples, although there was a greater amount of pit and groove caries in the Ouachita River sample which she attributes to a high carbohydrate diet. Again, the caries data for the Sanders population more closely resembles the Ouachita River sample frorm Bumett (1988) and the Caddo population sample from Powell (1985) than either the Standridge Caddo or Fourche Maline samples.

Table 2.

Caries Locations and Type from the Sanders Site

Location/Type Distribution among Caries

Location

Crown

Cervical margin

Root
82 percent $(140 / 171)$

13 percent $(23 / 171)$

5 percent $(8 / 171)$

\section{Type}

Pit and groove Interproximal Gross
65 percent $(110 / 170)$

20 percent $(34 / 170)$

15 percent $(25 / 170)$

Molars were the most frequently affected tooth type for canes in this population (Figure 6). This appears to be the case in most populations (Larsen et al. 1991). 


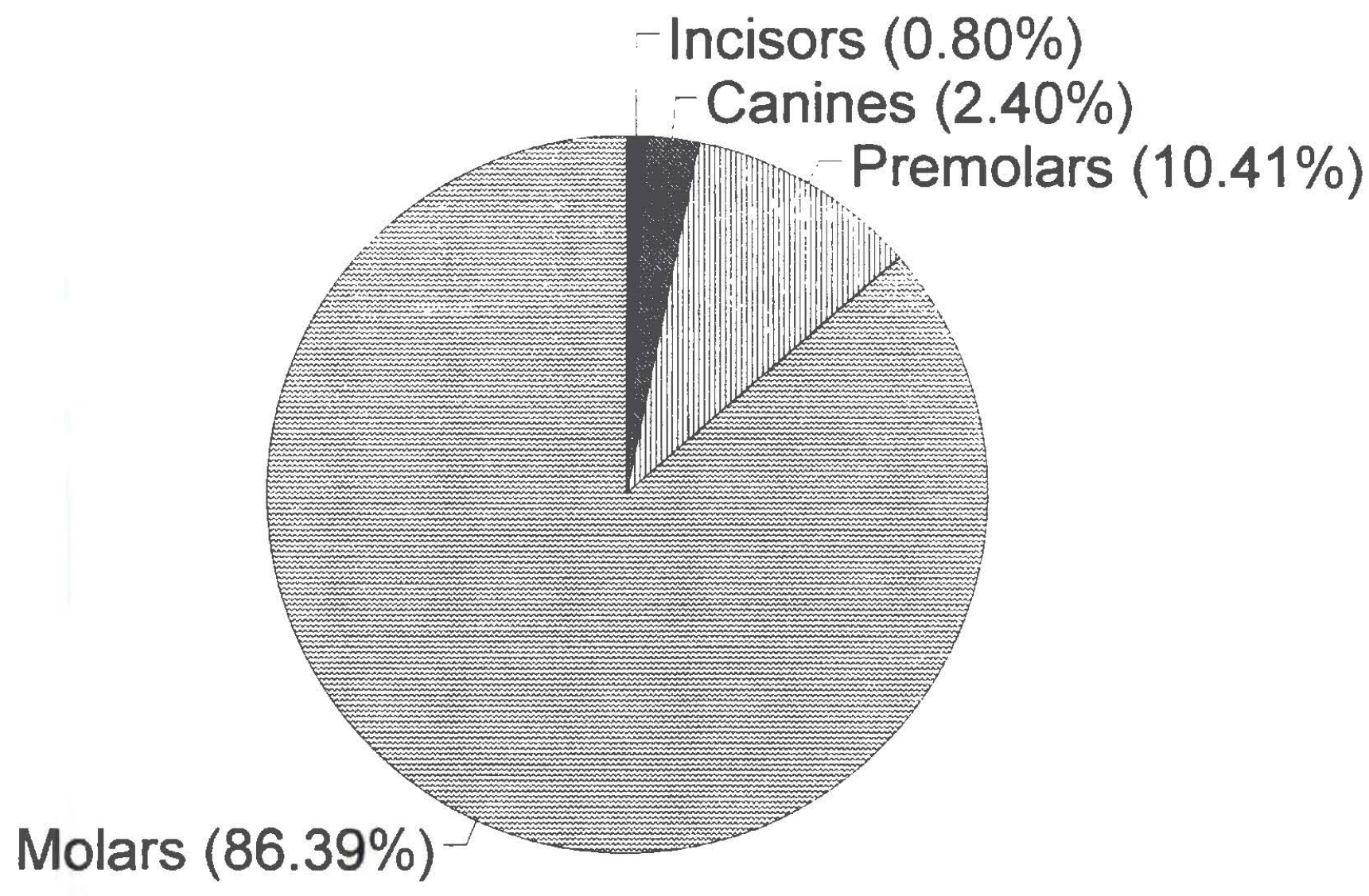

Figure 6. Frequency of Carious Teeth by Type.

\section{Dental Attrition}

Caries rates may also be related to differential wear. Wear was estimated using both the Smith (1984) and Scott (1979) techniques. Angle of attrition was not scored in this analysis. Interobserver error was not a problem since the author was the only individual analyzing the data. Interobserver error, however, should be considered when comparing results presented here with other data sets. In order to see if both techniques produced the same result, I ran a correlation on score averages for all molars: a Pearson's $\mathrm{R}$ value of 0.73 . This suggests that the 
two measures are in fact related. The average tooth score for all molars is presented in Table 3.

Table 3.

Mean Molar Wear in the Sanders

Population

\begin{tabular}{lccc}
\hline Molar & Number of Teeth & Mean Wear & \\
& & & $\begin{array}{l}\text { Mean } \\
\text { Wear }\end{array}$ \\
\hline & & & \\
$\mathrm{RM}^{3}$ & 17 & 10.5 & 2.7 \\
$\mathrm{RM}^{2}$ & 33 & 12.3 & 3.0 \\
$\mathrm{RM}^{1}$ & 34 & 18.0 & 4.1 \\
$\mathrm{LM}^{1}$ & 31 & 19.2 & 4.1 \\
$\mathrm{LM}^{2}$ & 24 & 11.5 & 2.7 \\
$\mathrm{LM}^{3}$ & 14 & 10.6 & 2.4 \\
$\mathrm{LM}_{3}$ & 24 & 10.6 & 2.5 \\
$\mathrm{LM}_{2}$ & 25 & 12.2 & 3.1 \\
$\mathrm{LM}_{1}$ & 30 & 17.6 & 4.0 \\
$\mathrm{RM}_{1}$ & 26 & 16.1 & 3.5 \\
$\mathrm{RM}_{2}$ & 20 & 14.0 & 3.1 \\
$\mathrm{RM}_{3}$ & 18 & 14.0 & \\
\hline
\end{tabular}

1 Following Scott (1979)

2 Using Smith (1984)

Molar wear was calculated based on methods by Scott (1979) and Smith (1984). Although wear scores are not exactly evenly distributed by counterpart, mandibular and maxillary dentitions produced relatively even amounts of wear.

Since Scott's (1979) method was felt to be a more detailed measure of wear, it was used to test for difference in wear patterns between the sexes (Figure 7). Wear scores were averaged and individuals were grouped into age categories of ten year intervals. When individuals could not be placed into these categories they were omitted. A two-tailed Student's $t$ test found no statistically significant differences between the female and male populations. This suggests that differential caries rates were not the result of differential attrition.

Several tests were performed to determine if wear was age progressive. Figure 7 shows that wear was clearly age progressive, and this can be seen in the 
various regression analyses that predict linear relations for wear and age. Scores using the Scott (1979) method yielded a good correlation coefficient, using Pearson's R, of 0.73 ; however, only 54 percent of the data could be explained in the resulting regression formula. When sex was added to the equation, 62 percent of the data could be explained by the best fit regression calculated. The least square value resulting from this equation must be minimized so the Smith (1984) method score were also analyzed for best fit regression analyses.

Again, wear scores for all individuals were averaged and compared to age. Smith's (1984) scoring procedure produced slightly less robust correlations with age and higher least square values. However, since the best fit regression formula was being sought, individual teeth were tested to see which one(s) correlated best with age. Since Smith's (1984) scaling method allows for the scorig of all teeth, it was used for this application. The best represented teeth were selected for analysis, and that included all teeth with 30 or more represented. All third molars were also included because it was felt that they might present the clearest picture of adult wear patterns due to their late age of eruption. Teeth included in this analysis were: $\mathrm{RM}^{3}, \mathrm{RM}^{2}, \mathrm{RM}^{1}, \mathrm{RP}^{4}, \mathrm{RP}^{3}, \mathrm{LP}^{3}, \mathrm{LM}^{1}, \mathrm{LM}^{3}, \mathrm{LM}_{1}, \mathrm{LM}_{3}$, and $\mathrm{RM}_{3}$. None of the third molars were represented by 30 or more observations. Looking at Figure 7 it can be seen that tooth wear seems to be a good predictor of age until the 40 year category is reached.

By far the best fit was predicted using the maxillary left first molar, which produced an $R^{2}$ value of 0.83 and a least square value of 844 . Curiously, when sex was added to the equation, the correlation was less, and produced a least square value of 1649 . This suggests, however, that the attrition seen on the maxillary left first molar is due to normal circumstances of chewing rather than idiosyncratic, or sex-linked, behaviors. 


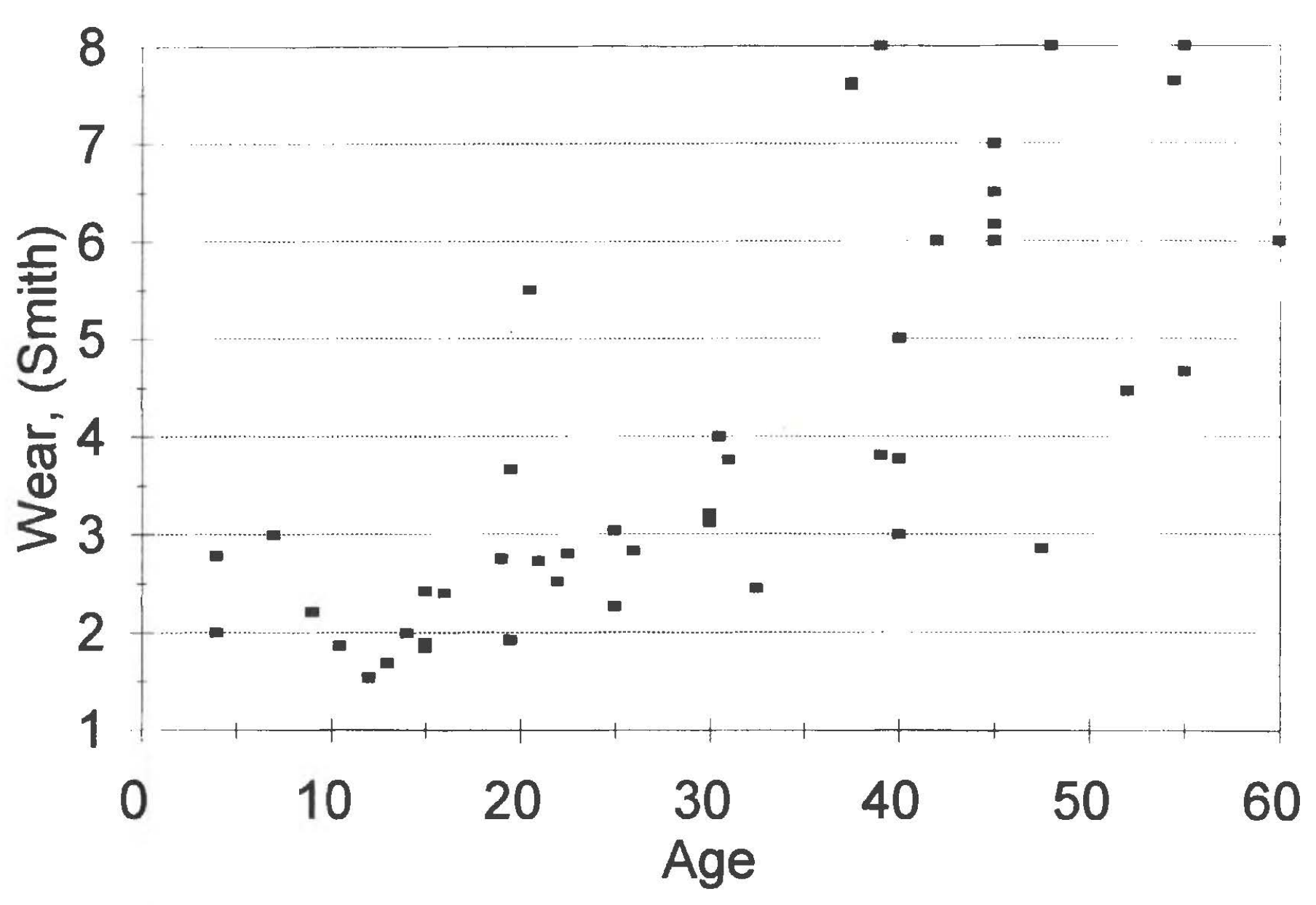

Figure 7. Distribution of Wear Patterns in the Sanders Population.

Other teeth that also produced a regression equation that predicted age for more than 75 percent of the population were the mandibular left third molar, and the maxillary left third premolar. All teeth used except the right maxillary second molar and third premolar, and the right mandibular molar yielded regression equations that predicted age for better than 70 percent of the population. I have, 
therefore, concluded that tooth wear is a valid means for predicting the age of individuals within the Sanders population.

Table 4 presents tooth wear scores for females and males on the three best indicators of age. The large jump in wear scores from ages 30-39 to 40-49 becomes very clear; however, the reason for this is unclear. It is possible that this dramatic difference is the result of relatively few older adults surviving beyond 39 years, hence most of the population died before dental attrition reached this point. It is also possible that once enough enamel has been removed from the occlusal surface the amount of wear that occurs on the exposed dentin undermines and weakens the remaining enamel, resulting in exponential loss of enamel at a critical stage.

Table 4.

\section{Tooth Wear Scores for Females and Males}

\begin{tabular}{|c|c|c|c|c|c|}
\hline Tooth & Age & Fermale N & Female $\mathrm{x}$ score & Male N & $\begin{array}{r}\text { Male } \\
\text { x score }\end{array}$ \\
\hline $\mathrm{LM}^{1}$ & $\begin{array}{l}15-19 \\
20-29 \\
30-39 \\
40-49 \\
50+\end{array}$ & $\begin{array}{l}5 \\
3 \\
3 \\
2 \\
1\end{array}$ & $\begin{array}{l}3.0 \\
2.7 \\
5.0 \\
6.5 \\
6.0\end{array}$ & $\begin{array}{l}1 \\
2 \\
3 \\
3 \\
2\end{array}$ & $\begin{array}{l}2.0 \\
2.5 \\
4.3 \\
5.3 \\
6.5\end{array}$ \\
\hline $\mathrm{LM}_{3}$ & $\begin{array}{l}15-19 \\
20-29 \\
30-39 \\
40-49 \\
50+\end{array}$ & $\begin{array}{l}3 \\
2 \\
1 \\
2 \\
-\end{array}$ & $\begin{array}{l}2.0 \\
1.0 \\
2.0 \\
4.0 \\
-\end{array}$ & $\begin{array}{l}- \\
2 \\
2 \\
3 \\
2\end{array}$ & $\begin{array}{l}- \\
2.5 \\
2.0 \\
4.3 \\
5.5\end{array}$ \\
\hline $\mathrm{LP}^{3}$ & $\begin{array}{l}15-19 \\
20-29 \\
30-39 \\
40-49 \\
50+\end{array}$ & $\begin{array}{l}5 \\
4 \\
3 \\
1 \\
-\end{array}$ & $\begin{array}{l}2.2 \\
2.2 \\
4.0 \\
5.0 \\
-\end{array}$ & $\begin{array}{l}1 \\
2 \\
3 \\
3 \\
2\end{array}$ & $\begin{array}{l}1.0 \\
2.5 \\
3.0 \\
4.0 \\
4.5\end{array}$ \\
\hline $\mathrm{RP}^{4}$ & $\begin{array}{l}15-19 \\
20-29 \\
30-39 \\
40-49\end{array}$ & $\begin{array}{l}5 \\
3 \\
3 \\
2\end{array}$ & $\begin{array}{l}2.2 \\
2.0 \\
4.3 \\
6.0\end{array}$ & $\begin{array}{l}1 \\
2 \\
3 \\
3\end{array}$ & $\begin{array}{l}1.0 \\
2.5 \\
2.7 \\
3.7\end{array}$ \\
\hline & $50+$ & 1 & 8.0 & 2 & 4.5 \\
\hline
\end{tabular}


Table 4, cont.

\begin{tabular}{llllll}
\hline & & & & & \\
$\mathrm{RM}^{1}$ & $15-19$ & 5 & 3.4 & 1 & 2.0 \\
& $20-29$ & 4 & 3.8 & 3 & 5.3 \\
& $30-39$ & 2 & 4.0 & 3 & 5.0 \\
& $40-49$ & 2 & 7.0 & 3 & 5.0 \\
& $50+$ & 1 & 7.0 & 2 & 6.5 \\
$\mathrm{LM}^{3}$ & $15-19$ & 1 & 1.0 & - & \\
& $20-29$ & 2 & 4.0 & 1 & 1.0 \\
& $30-39$ & 3 & 2.0 & 2 & 2.0 \\
& $40-49$ & 1 & 5.0 & 2 & 1.5 \\
& $50+$ & 2 & 5.0 & - & - \\
$\mathrm{LM}_{1}$ & $15-19$ & 6 & 2.5 & 1 & 2.0 \\
& $20-29$ & 2 & 4.0 & 2 & 3.0 \\
& $30-39$ & 1 & 5.0 & 1 & 2.0 \\
& $40-49$ & 2 & 6.0 & 4 & 5.2 \\
& $50+$ & - & - & 2 & 6.5 \\
& & & & &
\end{tabular}

Note: The trends in average wear scores are presented. Sample sizes are extremely small, and this may have influenced the results.

Rates of attrition can be correlated with the amount of grit and unprocessed vegetable fiber in the diet. It was expected that wear in this population would be relatively low because archaeological and ethnohistorical evidence suggested that there should be little grit in the diet. At contact the Caddo used large hollowed tree trunks as mortars and wooden pestles (Swanton 1942). The only stone grinding implements recovered from the Sanders site were two small "nutting/pigment" stones and several manos. These grinding implements had circular depressions that measured less than $14 \mathrm{~cm}$ in diameter, and it is doubtful that the use of two of them would have supplied substantial grit to the whole population's diet. Of course, it is possible that food was processed off-site with stone grinding implements.

Comparison with other populations has been difficult due to differentnt techniques used to measure and score wear pattems, not to mention because of interobserver error. Powell (1985) compared dental attrition among a Caddoan 
sample with a Fouche Maline sample and found significantly greater wear among the Fouche Maline, who used stone gnnding implements. Unfortunately, Powell (1985) used a different scoring technique, although also a 1-8 ranking system, like the Smith (1984) technique. In the Smith (1984) technique, stages 1-3 are based on cusp removal, while stages 4-8 are based on dentin exposure. The technique employed by Powell is based solely on dentin exposure.

Likewise, in Burnett's (1990) synthesis, dental attrition is listed as slight, moderate, and severe because in most of the literature attrition has been described in qualitative terms rather than scored. Interobserver error can become quite large when comparisons are made with this type of data. I would claim that the dental attrition at Sanders is moderate although how this compares with others observations of "moderate" is completely unknown. Burnett (1990) states that Caddoan populations in the Oauchita River drainage had slight dental attrition while Caddoan populations to the north in the Arkansas River drainage had heavy wear.

In the only analysis of Caddoan remains that used the Smith (1984) system, age was not accounted for and only mean wear scores were given (Burnett 1988:150). These data are compared with means from the Sanders site which is located considerably further to the southwest of the sites analyzed in the Middle Ouachita region. The Sanders means (see Table 2) fit well within the range for Middle Ouachita sites (M1:3.5-7.0; M2:2.8-6.0; M3: 2.0-3.8) and are higher than the scores given from the Standridge site (M1:2.0; M2:2.3; M3:2.7), which is located in the Ouachita Mountains, but near the Middle Ouachita comparative populations. This suggests that the Sanders population had comparable amounts of grit and/or unprocessed vegetable fiber in their diet. 


\section{Dental Abscess}

Dental abscess frequency was also noted as an indication of oral health. Both periapical and alveolar abscesses were lumped into one category since both are multifactorial in origin and can be caused by a number of factors including periodontal disease and exposure of the pulp cavity (Ortner and Putschar 1981). There were relatively few abscesses observed. Sixteen of the 51 individuals had evidence of abscessing ( 31 percent of the population). This amount falls between the Fourche Maline sample and the Caddo sample analyzed by Powell (1985). These 16 individuals had 23 total abscesses. All but three abscesses were located on the maxillary dentition. The two most commonly affected teeth were the maxillary left canine and first molar, accounting for five abscesses each. Because the left canine was so commonly affected, and abscesses generally occur more often on anterior teeth, caries did not correlate well with abscess frequency. A correlation analysis was run to see if the number and location of abscesses were related to dental attrition. The two were very weakly correlated with a Pearson's correlation coefficient of 0.32 . This suggests that wear was not the primary cause of dental abscesses.

\section{Antemortem tooth loss}

Antemortem tooth loss was also recorded as a final measure of dental health. Antemortem tooth loss is associated with age, carious activity, and periodontal disease. It was assumed that antemortem loss would increase with age. However this was not the case. One hundred and thirty-four teeth could be assessed as having been lost antemortem (these are not included in the 852 teeth examined). Peak loss occurred during the 30-39 year age interval ( $\mathrm{N}=47)$. In order to account for visibility, a ratio was constructed that took the number of teeth lost prior to death and divided it by the number of teeth present per age category. 
This was then multiplied by 100 to give an index of antemortem tooth loss (Table 5). Again the age category of 30-39 was most affected, followed by the $50+$ age category. This may simply mean that individuals affected by postmortem loss earlier in life were less likely to survive to the $50+$ year category.

\section{Table 5 .}

Antemortem Tooth Loss by Age

\begin{tabular}{ll}
\hline Age & Antemortem tooth loss index \\
\hline $20-29$ & $5.5(8 / 145)$ \\
$30-39$ & $34(47 / 138)$ \\
$40-49$ & $17(28 / 165)$ \\
$50+$ & $30(19 / 64)$
\end{tabular}

Note: The antemortem tooth loss index is equal to the total number of teeth lost before death divided by the number of teeth present per age category, multiplied by 100 .

Antemortem tooth loss occurred most frequently on the molars (Figure 8), and particularly $\mathrm{RM}_{1}(\mathrm{~N}=10)$ and $\mathrm{RM}_{2}(\mathrm{~N}=9)$. Powell (1985:331) reports that multiple rooted teeth were more often lost in both of her Caddo and Fouche Maline samples. This pattern of antemortem loss was similar to the caries pattern and so a correlation was run to see if the two were related. Pearson's R of 0.97 suggests that the two are highly correlated, and it is likely that abscessing results from caries that expose the pulp cavity to infectious agents.

Antemortem tooth loss was highly biased sexually. Males had 74 antemortem tooth losses, while females lost 46 teeth prior to death. This difference was significant in a Chi-square test at the 0.05 significance level. This is odd because antemortem tooth loss correlates well with caries frequency, yet females had higher caries frequencies. Males did out survive females slightly, but the amount, like the caries frequency, was insignificant. Gross caries were examined to see if they occurred more frequently with males, but they did not. Nevertheless, 
it is likely that the higher caries frequency seen in females is partly the result of higher antemortem loss of afflicted teeth among males.

Antemortem tooth loss is perhaps most directly the result of periodontal disease (Hillson 1986). The high incidence among males probably indicates a higher incidence of periodontal disease than that found among females. Conversely these results suggest that females who experience antemortem tooth loss are less apt to survive long enough to experience greater loss.

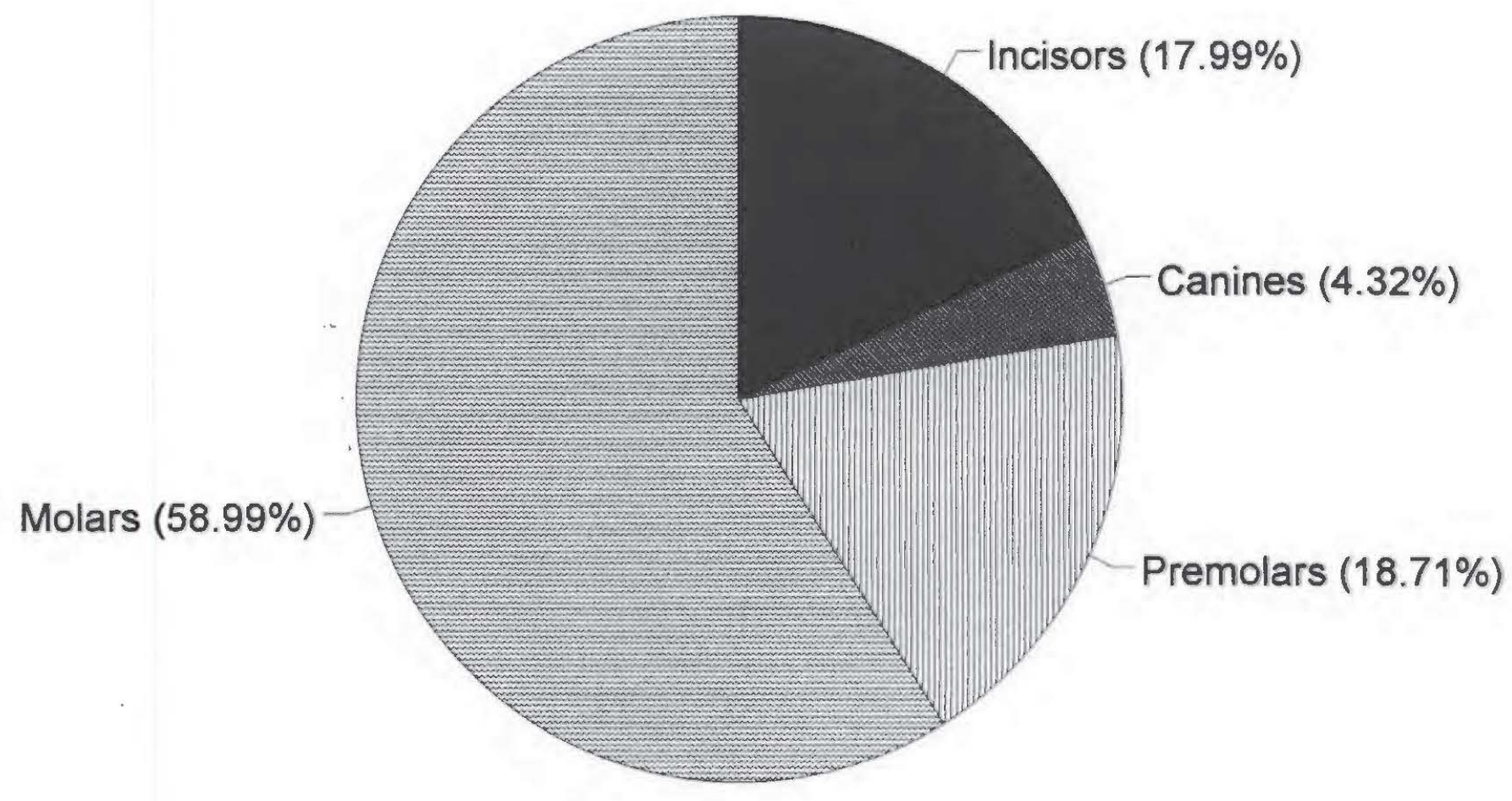

Figure 8. Frequency of Antemortem loss by tooth type. 


\section{Summary and Conclusions}

The preceding analyses have confirmed that the expected dental pathologies associated with maize agricultural populations were present in the Sanders population. Caries rates fell within the agricultural range of 2.3-26.9 percent (Turner 1979:624) for carious teeth. The high rate of caries is probably the result of the carbohydrate-rich diet that maize provides.

In the Caddo archaeological region dental attrition declines with the adoption of maize agriculture due to the ingestation of more soft, starchy foods, and replacement of stone grinding implements with wood. Lowered attrition may increase the prevalence of caries since locations of caries remain in place longer. Additionally abrasives may act to cleanse teeth of food particles (Powell 1985:323).

Abscess rates were moderate and fell within the range of Caddoan values for all locations listed by Burnett (1990) except the Cooper Lake sites. The majority of teeth lost before death may have been the result of destruction of supporting structures from abscessing. However, if this were the case a significantly greater proportion of males should have shown signs of abscesses than females. Instead frequencies of abscesses were evenly distributed between the sexes.

Besides differential rates of antemortem tooth loss, the Sanders population is relatively homogenous in terms of dental health. It also appears to fit well within the expected range of pathologies experienced by other Caddoan populations. Only with the addition of further comparative data sets will the question of Sanders site ethnic affiliation come closer to being resolved. 


\section{REFERENCES CITED}

Bruseth, J. E.

1995 The Development of Caddoan Polities Along the Middle Red River Valley of Eastern Texas and Oklahoma. In The Native History of the Caddo: Their Place in Southeastern Archaeology and Ethnohistory, edited by T. K. Perttula and J. E. Bruseth. MS in review for publication.

Bruseth, J. E., D. E. Wilson, and T. K. Perttula

1995 The Sanders Site: A Spiroan Entrepot in Texas? Plains Anthropologist, in press.

Buikstra, J. and D. Fowler

1975 An Osteological Study of the Human Skeletal Material from the BentsenClark Site. In The Bentsen-Clark Site, Red River County, Texas, by L. Banks and J. Winter, pp. 79-97. Special Publication No. 2. Texas Archeological Society, San Antonio.

Burnett, B. A.

1988 Bioarcheology of Standridge and the Middle Ouachita Caddoan. In Standridge: Caddoan Settlement in a Mountain Environment, by A. M. Early, pp. 143-153. Research Series No. 29. Arkansas Archeological Survey, Fayetteville.

1990 Part I: The Bioarcheological Synthesis of the Gulf Coastal Plain Study Area. In The Archeology and Bioarcheology of the Gulf Coastal Plain, by D. A. Story, J. A. Guy, B. A. Burnett, M. D. Freeman, J. C. Rose, D. G. Steele, K. J. Reinhard, and B. W. Olive, pp. 385-418. 2 Vols. Research Series No. 38. Arkansas Archeological Society, Fayetteville.

Butler, B. H.

1969 Analysis of the Human Skeletal Remains. In Archeological Investigations at the Sam Kaufman Site, Red River County, Texas, edited by S. A. Skinner, R. K. Harris, and K. M. Anderson, pp. 115-136. Contributions in Anthropology No. 5. Department of Anthropology, Southem Methodist University, Dallas. 
Cohen, M. N. and G. J. Armelagos (editors)

1984 Paleopathology at the Origins of Agriculture. Academic Press, New York. Hillson, S. W.

1979 Diet and Dental Disease. World Archaeology 11:147-162.

1986 Teeth. Cambridge University Press, Cambridge.

1scan, M. Y. and S. R. Loth

1986 Estimation of Age and Determination of Sex from the Sternal Rib. In Forensic Osteology: Advances in the Identification of Human Remains, edited by K. J. Reichs, pp. 68-89. Charles C. Thomas, Springfield, Illinois.

Kelley, M. A., D. R. Levesque, and E. Weidl

1991 Contrasting Patterns of Dental Disease in Five Early Northern Chilean Groups. In Advances in Dental Anthropology, edited by M. A. Kelley and C. S. Larsen, pp. 203-214. Wiley-Liss, New York.

Kestle, S.

1988 Subsistence and Sex Roles. In The King Site: Continuity and Contact in Sixteenth-Century Georgia, edited by R. L. Blakely, pp. 63-72. University of Georgia Press, Athens.

Krieger, A. D.

1946 Cultural Complexes and Chronology in Northern Texas. Publication No. 4640. University of Texas, Austin.

Larsen, C. S.

1984 Health and Disease in Prehistoric Georgia: the Transition to Agriculture. In Paleopathology at the Origins of Agriculture, edited by M. N. Cohen and G. J. Armelagos, pp. 367-392. Academic Press, New York.

Larsen, C. S., R. Shavit, and M. C. Griffin

1991 Dental Caries Evidence for Dietary Change: An Archaeological Context. In Advances in Dental Anthropology, edited by M. A. Kelley and C. S. Larsen, pp. 179-202. Wiley-Liss, New York. 
Lovejoy, C. O. et al.

1985 Multifactorial Determination of Skeletal Age at Death: A Method and Blind Tests of its Accuracy. American Journal of Physical Anthropology 68:1-14.

McKern, T. W. and T. D. Stewart

1957 Skeletal Age Changes in Young American Males: Analyzed from the Standpoint of Age Identification. Technical Report EP-45. Environmental Protection Research Division, Quartermaster Research and Development Center, U.S. Army. Natick, Massachusetts.

Meindl, R. S. and C. O. Lovejoy

1985 Ectocranial Suture Closure: a Revised Method for the Determination of Skeletal Age at Death based on the Lateral-Anterior Sutures. American Journal of Physical Anthropology 68:57-66.

Molnar, S.

1971 Human Tooth Wear, Tooth Function, and Cultural Variability. American Journal of Physical Anthropology 54:27-42.

Newkumet, V. B. and H. L. Meredith

1988 Hasinai: A Traditional History of the Caddo Confederacy. Texas A\&M University Press, College Station.

Ortner, D. J. and W. G. J. Putschar

1981 Identification of Pathological Conditions in Human Skeletal Remains. Contributions to Anthropology No. 28. Smithsonian Institution, Washington, D.C.

Parsons, E. C.

1941 Notes on the Caddo. Memoirs No. 57. American Anthropological Association, Washington, D.C. 
Perttula, T. K.

1993 "Kee-Oh-Na-Wah'-Wah": The Effects of European Contact on the Caddoan Indians of Texas, Louisiana, Arkansas, and Oklahoma. In Ethnohistory and Archaeology, edited by J. D. Rogers and S. M. Wilson, pp. 89-109. Plenum Press, New York.

Powell, M. L.

1985 The Analysis of Dental Wear and Caries for Dietary Reconstruction. In The Analysis of Prehistoric Diets, edited by R. I. Gilbert, Jr. and J. H. Mielke, pp. 307-338. Academic Press, Orlando.

Powell, M. L. and J. D. Rogers

1980 Bioarcheology of the McCutchan-McLaughlin Site (34Lf-11): Biophysical and Mortuary Variability in Eastern Oklahoma. Studies in Oklahoma's Past No. 5. Oklahoma Archeological Survey, Norman.

Rose, J. C., B. A. Burnett, M. S. Nassaney, and M. Blaeuer

1984 Paleopathology and the Origins of Maize Agriculture in the Lower Mississippi Valley and Caddoan Culture areas. In Paleopathology at the Origins of Agriculture, edited by M. N. Cohen and G. J. Armelagos, pp. 393-424. Academic Press, New York.

Rose, J. C. and M. K. Marks

1985 Bioarcheology of the Alexander Site. In The Alexander Site, Conway County, Arkansas, edited by E. T. Hemmings and J. H. House, pp. 79-98. Research Series No. 24. Arkansas Archeological Survey, Fayetteville.

Schambach, F. F.

1993 Some New Interpretations of Spiroan Culture History. In Archaeology of Eastern North America: Papers in Honor of Stephen Williams, edited by J. B. Stoltman, pp. 187-230. Archaeological Report No. 25. Mississippi Department of Archives and History, Jackson. 
Scott, E. C.

1979 Principal Axis Analysis of Dental Attrition Data. American Journal of Physical Anthropology 58:203-211.

Smith, B. H.

1984 Patterns of Molar Wear in Hunter-Gatherers and Agriculturists. American Journal of Physical Anthropology 63:39-56.

1991 Standards of Human Tooth Formation and Dental Age Assessment. In Advances in Dental Anthropology, edited by M. A. Kelley and C. S. Larsen, pp. 143-168. Wiley-Liss, New York.

Steele, D. G. and C. A. Bramblett

1988 The Anatomy and Biology of the Human Skeleton. Texas A\&M University Press, College Station.

Stewart, T. D.

1979 Essentials of Forensic Anthropology Especially as Developed in the United States. Charles C. Thomas, Springfield, Illinois.

Stodder, A. L. W. and D. L. Martin

1992 Health and Disease in the Southwest before and after Spanish Contact. In Disease and Demography in the Americas, edited by J. W. Verano and D. H. Ubelaker, pp. 55-74. Smithsonian Institution Press, Washington, D.C. Story, D. A.

1990 Cultural History of the Native Americans. In The Archeology and Bioarcheology of the Gulf Coastal Plain, by D. A. Story, J. A. Guy, B. A. Burnett, M. D. Freeman, J. C. Rose, D. G. Steele, K. J. Reinhard, and B. W. Olive, pp. 163-366. 2 Vols. Research Series No. 38. Arkansas Archeological Survey, Fayetteville. 
Swanton, J. R.

1942 Source Material on the History and Ethnology of the Caddo Indians.

Bulletin 132. Bureau of American Ethnology, Smithsonian Institution, Washington, D.C.

Turner, C. G., II

1979 Dental Anthropological Indications of Agriculture among the Jomon People of Central Japan. American Journal of Physical Anthropology 58:101-106. Ubelaker, D. H.

1978 Human Skeletal Remains: Excavation, Analysis, Interpretation. Taraxacum, Washington, D.C.

Walker, P. L.

1986 Sex Differences in the Diet and Dental Health of Prehistoric and Modern Hunter-Gatherers. Paper presented at the European meeting of the Paleopathological Association, Madrid.

Walker, P. L. and B. S. Hewlett

1990 Dental Health, Diet, and Social Status among the Central African Foragers and Farmers. American Anthropologist 92:383-398.

Webb, C. H.

1959 The Belcher Mound: A Stratified Caddoan Site in Caddo Parish, Louisiana. Memoirs No. 16. Society for American Archaeology, Salt Lake City, Utah.

Wilson, D. W. and D. Cargill

1993 Stable Isotope Analysis from the Sanders Site. Caddoan Archeology Newsletter IV (No. 3):3. 